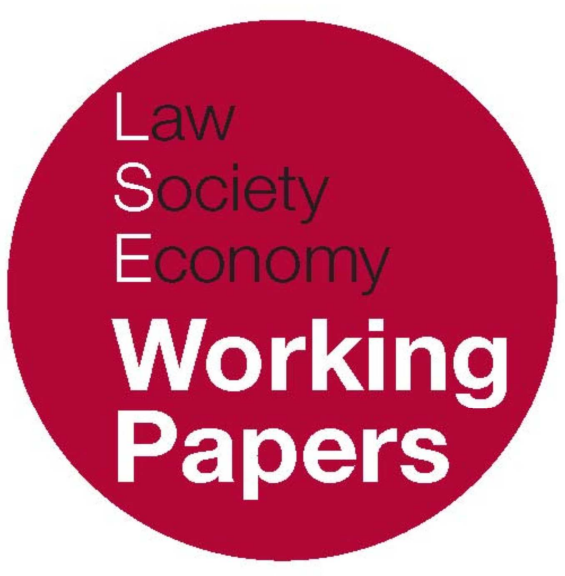

\title{
The Evolution of Sufficiency in \\ Common Law
}

\author{
Sivaramjani Thambisetty
}

LSE Law, Society and Economy Working Papers 6/2013

London School of Economics and Political Science

Law Department

This paper can be downloaded without charge from LSE Law, Society and Economy Working Papers at: www.lse.ac.uk/collections/law/wps/wps.htm and the Social Sciences Research Network electronic library at: http://ssrn.com/abstract=2212064.

(C) Sivaramjani Thambisetty. Users may download and/or print one copy to facilitate their private study or for non-commercial research. Users may not engage in further distribution of this material or use it for any profit-making activities or any other form of commercial gain. 


\title{
The Evolution of Sufficiency in Common Law
}

\author{
Sivaramjani Thambisetty *
}

\begin{abstract}
The requirement of disclosure in the patent specification is commonly presented as an essential arm of the patent bargain. This paper tests the assumption that disclosure requirements in a number of common law jurisdictions continue to reflect this and other shared origins of this doctrine. Instead we see forces such as Europeanisation and sectorspecificity produce divergence and confusion over the purpose of sufficiency, particularly in the context of adjacent patentability criteria such as utility and nonobviousness. The result is a complex expression of this requirement that has eroded the normative strength of this doctrine as originally expressed in Liardet $\mathrm{v}$ Johnson.
\end{abstract}

Key words: sufficiency, disclosure, utility, enablement, nonobviousness, breadth of claims, novelty, Liardet v Johnson.

\footnotetext{
* Lecturer in Law, London School of Economics and Political Science. A version of this paper was previously published as a chapter in: Bently, Lionel and $\mathrm{Ng}$, Catherine W. and D'Agostino, Giuseppina, (eds., 2010) The Common Law of Intellectual Property: Essays in Honour of Professor David Vaver. Hart Publishing, Oxford, UK, pp. 199-220.
} 
The requirement that a patent should include a specification that contains a description of the invention, allowing a person skilled in the art to practise, use or work the invention, is a basic tenet of modern patent law in a number of jurisdictions. Several legal histories have thrown light on this requirement, which was at one time a new concept in the common law. Recent work has corrected Hulme's earlier contention that Mansfield's decision in Liardet v Johnson $(1778)^{1}$ was a departure from previous English practice. Adams and Averley, and Walterscheid among others, note that the specification developed some time at the beginning of the eighteenth century when law officers began to require a written specification as a condition of the patent grant and thereafter to make it a routine requirement. ${ }^{2}$

There is also a subtle point of disagreement on whether Liardet amounted to the mere formalisation of the gradual change in the law from what the inventor brings by way of personal effort and capital to the disclosure in the patent specification, or in fact spelt the beginning of the end of this process. ${ }^{3}$ Some time before Lord Mansfield's observations in this case, the principal aim of the patent grant shifted. Indeed, 'neither specification nor written disclosure was required in the vast majority of Elizabethan grants' 4 a feature that follows from the original consideration offered for monopoly privileges - to work the industry and train English apprentices. ${ }^{5}$ However, there seems to be general agreement that Lord Mansfield's third instruction to the jury in Liardet formalised the point at which the law began to accept written descriptions as a condition and requirement of the patent grant:

The third point is whether the specification is such as instructs others to make it. For the condition of giving encouragement is this: that you must specify upon record your invention in such a way as to teach an artist, when the term is out, to make it - and to make it as well by your directions: for then at the end of the term, the public shall have benefit of it.

The disclosure in the patent specification has since then been restated in terms of a 'contract', a quid pro quo with the state in return for the grant of a patent. MacLeod, for example, writes that with the above words, 'for the first time, the recognised quid pro quo for the award of a patent was the disclosure of the invention'. 6 Mossoff in particular suggests that the restatement of the substantive

\footnotetext{
${ }^{1}$ Liardet v Johnson (1778) 1 WPC 53 (reproduced in Hayward's Patent Cases, vol 1, 196-201).

2 JN Adams and G Averley, 'The Patent Specification: The Role of Liardet v Johnson' (1986) 7 Journal of Legal History 156-177 and EC Walterscheid, To Promote the Progress of Useful Arts: American Patent Law and Administration, 1798-1836 (Rothman and Co, Colorado 1998) 399-420.

3 Adams and Averly 'The Patent Specification' (n 2).

${ }^{4}$ RA Klitzke, 'Historical Background of the English Patent Law' (1959) 41 Journal of the Patent Office Society 615, 641-642.

${ }^{5}$ See C MacLeod, Inventing the Industrial Revolution: The English Patent System, 1660-1800 (Cambridge, CUP, 2002) 48-49.

${ }^{6} \mathrm{Ibid}$ 49. Also see Walterscheid, To Promote the Progress of Useful Arts (n 2) 404.
} 
principle behind the requirement of the specifications was in effect predicated on a natural rights approach to patents, specifically Locke's social contract theory. ${ }^{7}$

Over-use of this imprecise 'quid pro quo' metaphor can lead to confusion particularly as the interpretation of the 'contract' is entrusted to two different tribunals. Others have noted that the so-called contract theory or bargain is useful not as a justification but as an explanation in law of the mechanics of the evaluation and granting of patents. ${ }^{8}$ The origin of the patent specification appears historically to be rooted in an instrumental view of what the patent system could achieve and what was administratively most feasible ${ }^{9}$ - an approach that endures within some contexts of modern disclosure requirements (such as 'subjective' best mode disclosures in the US and timing of amendments in Australian law). In modern patent statutes, an expedient approach to disclosure requirements is perhaps best reflected in the lack of detail in many provisions describing sufficiency. This lack of detail has facilitated diverse legal doctrines and outcomes in different jurisdictions, even in association with apparently simple requirements.

Professor Vaver refers to the contract or bargain metaphor as nothing more than a rhetorical flourish whose sustained use is damaging to certainty in intellectual property law. ${ }^{10}$ At the very least, the idea glosses over the prosaic institutional and administrative beginnings of the requirement to provide a specification; at worst, the metaphor is a source of error and confusion. The discussion in this chapter attempts to demonstrate that although the bargain metaphor is a useful indicator of the common history of patents, the idea may be used to justify so many variations on what amounts to sufficient disclosure that it is of little analytical value. This chapter focuses on two aspects of contemporary common law: the divergence in sufficiency requirements and the overlap between sufficiency and other criteria of invalidity. Both aspects expose distortions of the bargain metaphor, leading to potential for confusion and error.

7 A Mossoff, 'Rethinking the Development of Patents: An Intellectual History, 1550-1800' (2001) 52 Hastings Law Journal 1255.

8 WC Robinson, The Law of Patents for Useful Inventions (Boston, Little Brown, 1890) 59.

9 MacLeod believes the rise of the specification in the early to mid-eighteenth century shifted responsibility from the law officers to the courts thus allowing the system to be self-policing and the law officers to be spared much tedious investigation. MacLeod, Inventing the Industrial Revolution (n 5) 51, 53.

10 D Vaver, Intellectual Property Law: Copyright, Patents, Trademarks (Toronto, Irwin Law, 1977) 12-13, suggesting that the metaphor or analogy was perhaps more useful in the eighteenth century when intellectual property laws were cryptic and each patent was self-contained and spelt out the conditions of its grant. See also Tim Roberts, 'Sufficiency of Disclosure (Enabling Disclosure, Disclosure of Prior Art, Best Mode' (2006), available at

<http://www.wipo.int/meetings/en/2006/scp_of_ge_06/presentations/scp_of_ge_06_roberts.pdf> accessed $5^{\text {th }}$ April 2009. 


\section{ARE PATENT DISCLOSURES USEFUL SOURCES OF TECHNICAL INFORMATION?}

It is useful first to consider briefly the continued relevance in a modern context of the aim of disclosure stated so clearly in Liardet, principally whether 'the specification is such as instructs others to make it'. What is the true value of patent disclosures - are patent specifications useful sources of technical information? Machlup and Penrose point out that although the diffusion of technology through patent disclosures is an old argument, economists have been sceptical of it at least since the 1950s. ${ }^{11}$ Not all patentable inventions are patented and concealable inventions remain concealed; ${ }^{12}$ therefore, the argument goes that patents reveal little that would not otherwise be revealed. ${ }^{13}$ Economic literature is peppered with explicit findings that patent disclosures appear to have no measurable impact on information flows from other firms and therefore no measurable impact on $\mathrm{R} \&$ D productivity. ${ }^{14}$

However, case law in a number of jurisdictions weaves a different narrative, and observations such as those made in Paulik $v$. Rizkalla remain exceptional but valuable indicators of the significance of technical disclosures in patents:

The obligation to disclose is not the principal reason for a patent system; indeed, it is a rare invention that cannot be deciphered more readily from its commercial embodiment than from the printed patent. ${ }^{15}$

Clarisa Long mirrors this concern when she emphasises that patents often tell observers more about the patentee (for example about the financial prospects of the firm) than the invention itself. ${ }^{16}$

An interesting insight into the disparity between legal reasoning and economic accounts is provided by recent empirical surveys that highlight the increasing complexity and voluminosity of patent applications. ${ }^{17}$ Does this

11 F Malchup and E Penrose, 'The Patent Controversy in the Nineteenth Century' (1950) 10(1) The Journal of Economic History 1-29.

${ }^{12}$ However, see J Bessen, 'Patents and The Diffusion of Technology', available at www.researchoninnovation.org/disclose.pdf.

${ }^{13}$ See B Roin, 'Disclosure Function of the Patent System (Or Lack Thereof)' (2005) 118(6) Harvard Law Review 2007, debunking several assumptions about whether patents disseminate technical information.

14 A Arora et al, 'R\&D and the Patent Premium' NBER Working Paper No 9431, 2003. available at www.nber.org/papers/w9431. Also see W Cohen et al, 'R\&D Spillovers, Patents and the Incentives to Innovate in Japan and the United States' (2002) 31(8-9) Research Policy, 1349-67 and M Hall et al, 'Barriers to the Use of Patent Information in UK Small and Medium-Sized Enterprises: Part 2(1): Results of In-depth Interviews' (2000) 26(2) Journal of Information Science 87-99, 94.

15 Paulik, $v$ Rizkalla 760 F 2d 1270, 1276 (Fed Cir. 1985).

${ }^{16}$ C Long, 'Patent Signals' (2002) 69 University of Chicago Law Review 625-679. Also see L Oppenheim, 'How SMEs Use the Patent Literature' Summary Report for the UK Economic and Social Research Council (1998).

${ }^{17}$ Based on the number of pages and number of claims. The study also considers other parameters of size with respect to other recent surveys. E Archontopoulous et al, 'When Small is Beautiful: Measuring the Evolution and Consequences of the Voluminosity of Patent Applications at the EPO', CEB Working 
development indicate a more thorough disclosure of inventions, or does it merely represent disruptive strategies, such as creating uncertainty by 'polluting the technological field or circumventing disclosure requirements by hiding major inventions'?18

Zeebroeck's study points out several results that shed light on the effect of varied disclosure requirements in the law. ${ }^{19}$ For example, emerging sectors (biotech, computer science, audio, video and medial technologies) with less established vocabulary and practices can lead to larger patent applications than more traditional areas. ${ }^{20}$ Drafting styles also account for important differences between civil and common law countries, with the latter having much longer patents on average. This difference would not be a problem for the common law in itself but for the increasing success of the PCT route, resulting in the harmonisation of drafting styles worldwide towards the US model. ${ }^{21}$

However, it is often substantive legal requirements that lead to voluminous disclosures. These include the doctrine of equivalents in the US that effectively encourages applicants to embed within their drafts detailed fall-back options that can be used in case of litigation, to salvage as much of the scope of the patent as possible. The mandatory best mode requirement in US applications often results in patentees detailing several utilisation modes to hide the 'best' one, possibly leading to longer descriptions.

Additionally, although it is in the public interest to have all prior art considered by the patent office, only US law takes a stringent view on the disclosure of prior art. The patent applicant is obliged to disclose all prior art of which he is aware, failing which the patent may be unenforceable, possibly triggering treble damages in infringement actions. This approach can lead to an if in doubt, disclose' rule, resulting in long lists of marginal relevance, making examination more difficult and adding to the expense of litigation. ${ }^{22}$ On the other hand, the UK and Australia do not require specific disclosure of relevant art, except for citations made in parallel applications prosecuted in other countries. ${ }^{23}$ Changes to New Zealand's Patents Act 1953, expected to come into effect this year, will require similar disclosure of the results of prior art searches made on corresponding overseas applications relating to the same invention. ${ }^{24}$ Despite these differences if the application is filed through the PCT route and claims US

Paper 06/019 (2006). Also see JW Dudas, 'The Patent System Today and Tomorrow', Statement Before the Subcommittee on The Judiciary, United States Senate (2005).

18 Archontopoulous, 'When Small is Beautiful' (n 17).

${ }^{19} \mathrm{~N}$ van Zeebroeck et al, 'Claiming More: The Increased Voluminosity of Patent Applications and its Determinants', Working Paper CEB 06-018 RS (2006).

20 This resonates with 'intrinsic uncertainty' in emerging technologies. S Thambisetty, 'Patents as Credence Goods' (2007) 27 Oxford Journal of Legal Studies 707-40.

${ }^{21}$ Zeebroeck, 'Claiming More' (n 19).

22 T Roberts, 'Sufficiency of Disclosure (Enabling Disclosure, Disclosure of Prior Art, Best Mode' (2006), available

www.wipo.int/meetings/en/2006/scp_of_ge_06/presentations/scp_of_ge_06_roberts.pdf.

${ }^{23} \mathrm{Ibid}$, but see $\mathrm{r} 26$, EPO Guidelines.

${ }^{24}$ Patents Bill 235- (2008) cl 9. 
priority then it is likely to adopt the disclosure requirements of the US patent system by default.

\section{DISCLOSURE AND ENABLEMENT: TIMING, ANTICIPATION AND BEST MODE}

The centrality of disclosure remains an agreed principle in common law jurisdictions ${ }^{25}$ while insufficiency of disclosure is a ground for attacking the validity of a patent. ${ }^{26}$ The various twists and turns of this central principle in different jurisdictions beg the question of the quid pro quo. The following is a discussion of three features based on a common denominator that the specification must be sufficient to disclose the invention clearly enough and completely enough for it to be performed by a person skilled in the art without undue burden. Generally, 'the key word is "undue", not "experimentation". 27

First, the date of the assessment is pivotal because it indicates, inter alia, the content of the common general knowledge that may supplement the disclosure in the specification. In most jurisdictions including in the UK and US, the law requires that the invention be fully described at the date of filing of the application. However, in Australia, while section 40(2)(a) requires a 'complete specification to describe the invention fully including the best method known to the applicant of performing the invention', there is no further direction as to the date at which adequate disclosure is to be assessed. Case law has veered between the filing date and the date of patent grant.. ${ }^{28}$ In Pfizer Overseas Pharmaceuticals v Eli Lilly and Company ${ }^{29}$ the requirement of disclosing the best method known to the applicant was held satisfied by the full Federal Court even though the relevant method was introduced into the specification some three years after the filing.

The operative limitations on the power of amendment are the same in UK and Australian law. The test of added subject matter is whether a skilled man would, upon looking at the amended specification, learn anything about the

\footnotetext{
25 ss 14(3) and 14(5)(c), The UK Patents Act (linking concepts drawn from Arts 83 and 84 of the EPC, s 40 of the Australian Patents Act 1990, s 27 of the Canadian Patents Act 1985, 35 USC \ 112 (1986) and s 10, New Zealand Patents Act 1953).

26 In the UK s 72(1) (which does not as such include non-compliance with s 14(5)(c)), s 138(3) in Australia which cites the list of grounds for revocation, 35 USC $\int 282$ (2000), s 41(h), (i) New Zealand Patents Act 1953, s 53 Canadian Patents Act 1985.

${ }^{27} \mathrm{Re}$ Angstadt 537 F 2d 498, 504 (Cust and Pat App 1976). 'Undue burden' is sensitive to the nature of the invention, to the abilities of the skilled person, and the art in which the invention has been made. Wobben v. Vestas-Celtic Wind Technology Ltd [2007] EWHC 2636 (Pats) [197].

28 In Rescare Ltd v Anaesthetic Supplies Pty Ltd (1992) 111 ALR 205, an obiter comment by Gummow J noted that adequacy of disclosure must be judged with reference to the filing date. However, in Kimberly-Clark Australia Pty Ltd v Arico Trading International Pty Ltd (2001) 207 CLR 1 (Gleeson CJ, McHugh, Gummow, Hayne and Callinan JJ) the HC took an opposite view, stating that the relevant time was when the patent was granted.

29 Pfizer Overseas Pharmaceuticals v Eli Lilly and Company [2005] FCAFC 224.
} 
invention that he could not learn from the unamended specification, 30 including what is disclosed implicitly and explicitly. However, putting together the requirement of 'complete specification' with the scope of allowable amendments under section 102, the Australian Federal Court concluded that it is the specification as amended that must be construed for compliance with section 40(2)(a). On this basis the date for assessing complete disclosure was not earlier than the grant and could be as late as the date of commencement of proceedings.

While a key restraint on this aspect of disclosure continues to be the date at which common general knowledge is assessed, ${ }^{31}$ the possibility that new matter can be introduced into a specification as late as the date of grant of a patent is a serious divergence from other common law jurisdictions ${ }^{32}$ and is in effect a distortion of the 'bargain' metaphor; it potentially allows the applicant to withhold until grant the full nature of the invention and the means for performing it, leading to considerable uncertainty for the public and competitors.

Secondly, central to the law of sufficiency is 'enablement' - a concept that owes much to judicial exegesis. ${ }^{33}$ Under US law, $\$ 112$ is interpreted in such a way that three distinct requirements, including the enablement requirement (the other two being the written description and best mode requirement), are said to spring from it. ${ }^{34}$ In the UK enablement has been found to exist in a number of contexts in patent law, 35 and the principle 'explained in Beloit and General Tire has been accepted in Canada without reservation. ${ }^{3} 3$

In the context of sufficiency of disclosure there may be enablement even if the skilled man needed to correct obvious errors or depart in obvious ways from the teaching in the patent application - a concession that extends to the requirement for anticipatory enablement under novelty in the UK. ${ }^{37}$ Following on from Synthon, the Canadian Supreme Court accepted a two-part test whereby prior disclosure and enablement would need to be considered separately and proven for anticipation. Noting Lord Hoffmann's alignment of enablement in anticipation and sufficiency, the SC declined to consider whether the law in Canada is identical to the UK position. ${ }^{38}$

30 Richardson-Vicks Patent [1995] RPC 568, 576. Also see Corus Uk Ltd v Qual-Chem Ltd [2008] EWCA Civ 1177.

31 Pfizer v Eli Lilly (n 29) [327]-[328], [385]-[391]. The court stopped short of deciding whether there is a latest date by which an amendment may never be allowed in order to overcome a specification's failure to state the best method as required by s 40(2)(a). Also see discussion in [366]-[378]

32 'Getting the Balance Right: Toward a Stronger and More Efficient IP Rights System', IP Australia Consultation Paper (March 2009) [3.2].

33 Synthon BV v Smithkline Beecham Plc [2005] UKHL 59 [26]-[27]

34 R Merges, P Menell and M Lemley, Intellectual Property in the New Technological Age, $3^{\text {td }}$ edn (Aspen Publishers, 2003) 201.

35 Asabi Kasei Kogyo KK's Application [1991] RPC 485

36 Apotex Inc v Sanofi-Synthelabo Canada Inc 2008 SCC 61 [22] citing Free World Trust v Lectro Sant Inc 2000 SCC 66.

37 Synthon v Smithkline Beecham (n 33). A proposition previously rejected by the CA in BASF v Smithkline Beecham plc [2003] RPC 49.

38 Apotex v Sanofi-Synthelabo (n 36) [26]. 
While recognising the value of the phrase 'enabling disclosure' with respect to the disclosure required for anticipation of a process or method claim, the law in Australia finds little, if any, relevance of this phrase to the anticipation of a product claim or a claim for a chemical compound by formula. The novelty of a product claim lies in the product, and not the means of producing $i^{39}$ - this limited but significant divergence in the law of novelty destroying disclosures is compounded in another way.

Australian law requires that anticipatory disclosures be of appropriate quality to form the basis for revoking patents for want of novelty. The reverse infringement test is still a necessary condition for anticipation in UK law but it is no longer sufficient - a position that is shared historically in Australian law. ${ }^{40}$ But in an approach that is much narrower than 'enabling disclosure', laid out so elegantly by Lord Hoffmann in Synthon, Australian law requires anticipatory disclosures to teach (direct, recommend or suggest) the claimed invention with sufficient clarity ${ }^{41}$ and there will be no anticipation if the person skilled in the art was forced to 'rummage through the flag locker' to find a flag which the prior patentee possessed and could have raised. ${ }^{42}$

Thirdly, during the course of the eighteenth and nineteenth centuries, practice and common law had come to distinguish between the part of the specification in which the patentee discharged his duty to disclose the best way of performing the invention and the part that delimited the scope of the monopoly that he claimed. ${ }^{43}$ Historically a statement of the best method of performance of the invention as an integral aspect of the quid pro quo, was required even before statutes expressly required it. ${ }^{44}$ The duty of the patent applicant to disclose the best method of performing his invention continued in the UK until the changes brought about by the 1977 Act. ${ }^{45}$ It remains the law in the US where the specification must inter alia 'set forth the best mode contemplated by the inventor of carrying out his invention'. 46

How broadly the requirement sweeps has been a matter of considerable confusion and dispute. ${ }^{47}$ In the US ambiguity rises chiefly from the language in 35 USC $\int 112$, as 'mode' and 'carrying out the invention' are terms that are not

39 Apotex Pty Ltd (formerly GenRx Pty Ltd) v Sanofi-Aventis [2008] FCA 1194 [49].

40 Meyers Taylor Pty Ltd v Vicar Industries Ltd (1977) 137 CLR 228, 235

41 Bristol-Myers Squibb Co v FH Faulding and Co Ltd (2000) 97 FCR 524. Also see Nicaro Holdings v Martin Engineering (1990) 91 ALR 513 (the terms of the prior art must enable the skilled person to 'perceive and understand and be able practically to apply the discovery without the necessity of further experiments'.)

42 ICI Chemicals and Polymers Ltd v The Lubrizol Corp Inc [2000] FCA 1349 [51].

${ }^{43}$ Kirin Amgen v Hoechst Marion Roussel [2005] All ER 667, 677, Lord Hoffmann citing Fletcher-Moulton L $\mathrm{J}$ in British United Shoe Machinery v A Fussell and Sons (1908) 25 RPC 631, 650.

${ }^{44}$ Liardet v Johnson (n 1) 198

45 ss 32(1)(h) and 4(3)(b), 1949 Act.

4635 USC $\$ 102(\mathrm{~b})$.

${ }^{47}$ C Marchese, 'Confusion, Uncertainty and the Best Mode Requirement' (1992) 2 Federal Circuit Bar Journal 1. 
definable with precision. ${ }^{48}$ The requirement here, as in Australia ${ }^{49}$ and New Zealand, ${ }^{50}$ is designed to prevent a patentee from 'holding back' information, in effect maintaining part of the invention as a trade secret while protecting the whole under patent law. ${ }^{51}$ However, neither US nor Australian law ${ }^{52}$ requires the best mode to be identified, increasing the possibility of voluminous applications where a number of modes of performing the invention may be safely buried.

Further, under Australian law section 40(2)(a) requires a complete specification to 'describe the invention fully including the best method known to the applicant of performing the invention.' This is generally regarded as the requirement of sufficiency of description, ${ }^{53}$ for purposes of assessing which it is not necessary to disclose all alternative means. ${ }^{54}$ Given that the 'best method' requirement is an inclusion in the sufficiency requirement, it is subject to the same date of assessment, namely the date of grant (the date by which a complete specification, with amendments, if any, is filed). ${ }^{55}$ In contrast, the time for determining compliance with the 'best mode' in US law is the date of filing; this cannot be rectified subsequently by amendments. The divergence in timing is a challenge to the bargain metaphor as Australian law appears to allow the patentee to monopolise a greater field than has been disclosed to the public.

The 'best mode' requirement is emerging as a stormy issue in international harmonisation negotiations - the US, Brazil, India and Mexico are in favour of providing best mode disclosure, although most countries are against it. ${ }^{56}$ Given that Article 29(1) of the TRIPS Agreement states that members 'may' require the applicant to indicate the best mode for carrying out the invention known to the inventor at the filing date, or where priority is claimed, at the priority date of the invention; substantive harmonisation on best mode requirements seem unlikely to take place. However, as noted above, due to international filing strategies via PCT applications, it is likely to become the norm, at least in those applications that claim US priority.

\footnotetext{
48 Wabl Instruments Inc v Acvious Inc 950 F 2d 1575, 1579 (CAFC 1991). Also see C Marchese, 'Promoting the Progress of the Useful Arts by Narrowing Best Mode Disclosure Requirements in Patent Law' (1993) 54 University of Pittsburgh Law Review 589 and J Allison and M Lemley, 'Empirical Evidence on the Validity of Litigated Patents' (1998) 26 American Intellectual Property Law Association Quarterly Journal 185 (estimating that this 'subjective element of US patent law has been the cause of at least 10 per cent of all patent invalidations in the 1990s'. In Northern Telecom Inc v Datapoint Corp 908 F 2d 931, 946 (Fed Cir) Newman J observes that the best mode 'challenge is easy.'

${ }^{49}$ s $40(2)(a)$.

${ }^{50} \mathrm{~s} 10(3)(\mathrm{b})$.

$51^{\circ}$ The sole purpose of the best mode requirement is to restrain inventors from applying for patents while at the same time concealing from the public preferred embodiments of their inventions which they have in fact conceived.' Re Gay 309 F 2d 769, 772 (CCPA 1962).

52 Pfizer (n 29) [374].

53 Ibid [328].

${ }^{54}$ Lockwood Security Products Pty Ltd v Doric Products Pty Ltd [2004] HCA 58 [60].

${ }^{55}$ Pfizer (n 29) [347] - a position that is in keeping with English case law under the 1949 Act. C Van Der Lely NV v Ruston Engineering Co Ltd [1993] RPC 45 (56).

${ }^{56}$ C Correa, 'The Politics \& Practicalities of a Disclosure of Origin Obligation' (2005) 7/98 South Bulletin, February.
} 


\section{FAIR BASIS AND BROAD CLAIMS}

One of the most exciting recent developments in common law jurisdictions has been the reconsideration of Biogen $v$ Medeva ${ }^{57}$ by the House of Lords, in Generics (UK) Ltd v $H$ Lundbeck $A / S .{ }^{58}$ While the review of insufficiency is interesting in itself, it highlights the overlaps between insufficiency and other grounds of invalidity, and is of broad relevance to the assessment of the quid pro quo. The specific question framed as a matter of divergence between the UK and Australian law is this: how does the fair basing principle as a ground of invalidity differ between the UK and Australia, and what do these differences mean for the ability to prevent broad claims that are unsupported by adequate disclosure?

Modern insufficiency in the UK links two concepts drawn from EPC Articles 83 and 84 which are echoed in section 14(3) (requiring clear and complete disclosure) and section 14(5)(c) (requiring claims to be supported by the description) of the 1977 UK Patents Act. Although only the former is a basis for revocation under section 72, since Asabi, the requirements of section 14(3) have been read to necessarily include the latter. ${ }^{59}$ Thus the substantive effect of section 14(5)(c), namely that the description should, together with the rest of the specification, constitute an enabling disclosure, is given effect by section 72(1)(c).60

In Australian law there is a not dissimilar split, in that section 40(2)(a) of the Patents Act 1990 requires a complete specification to describe the invention fully (including the best method), and section 40(3) provides that the claim or claims be clear and succinct and fairly based on the matter disclosed in the specification. Unlike the fusion seen above in UK law, non-compliance of each is a distinct ground of revocation, as a result of which considerable judicial time has been spent on analysing what the 'fair basis' ground might involve that can invalidate a patent, over and beyond the requirement of a complete specification. ${ }^{61}$

In the UK, under the Patents Act 1949, an inventor was bound to disclose information about the invention in good faith and honesty, ${ }^{62}$ in addition to which section 32(1)(i) required that the claim be 'fairly based on the matter disclosed in the specification'. Both of these provisions are at the heart of the quid pro quo of patents, such as it exists. Before the introduction of this statutory fair basis objection in 1949, the House of Lords had formulated the substance of the provision in the following terms:

\footnotetext{
${ }^{57}$ Biogen v Medeva [1997] RPC 1 (HL).

${ }_{58}$ Generics (UK) Ltd v H Lundbeck. A/S [2009] UKHL 12.

59 Asabi Kasei Kogyo KK's Application [1991] RPC 485, 535-36.

${ }^{60}$ Biogen (n 57) 47.

${ }^{61}$ In particular see Lockwood v Doric (n 54).

62 The Patents Act 1949 s 32(1)(h) required the description to be fair and to disclose the best method known to the patentee. See WR Cornish and D Llewelyn, Intellectual Property: Patents, Copyright, Trade Marks and Allied Rights (London, Sweet \& Maxwell 2003) 164, 229-30.
} 
It is the consideration which the patentee gives to the public by disclosing his inventive idea which entitles him in return to protection for an article which embodies his idea, but not for an article which is described in terms which cover things quite unrelated to his idea and which do not embody it at all. ${ }^{63}$

The disappearance of these provisions, and the compulsion to follow related EPO authorities, led Lord Hoffmann to state in Biogen that the general principle of 'lack of fair basis' exists in substance so that where the breadth of the claims exceeds the invention disclosed the court may apply a broader approach to 'enabled disclosure'.

In Australian law as elsewhere, Biogen was interpreted as authority for the proposition that the breadth of a claim will exceed the 'technical contribution' to the art if it claims every way of achieving a result but only enables one such way. ${ }^{64}$ This decision created unease in Australia in a pre-Generics era and in the context of the lack of an explicit fair basis provision in the UK. Due to the fair basis provision in section 40(3), the decision was relegated in relevance, as being a better fit for the question of sufficiency in section 40(2). Thus the High Court in Lockwood Security Products took the position that it was 'Lord Hoffmann's view [...] that it was a requirement of English law that there be an enabling disclosure across the whole width of the claim. That is not and never has been the law in Australia'.65 Whether this really makes Australian law 'mechanistic and impoverished' in the sense in which Lord Hoffmann applied the words in Biogen to the general rule that an invention was sufficiently disclosed if the skilled man could make a single embodiment, is debatable. On fair basing however, it was enough for the Australian High Court to declare that current UK law is no guide to Australian law. 66

There is another persuasive reason for the High Court to move away from the UK's approach to fairness, and this is the confusion evident in Biogen and addressed explicitly in Generics regarding the so-called 'consistory', ${ }^{67}$ or 'covetous' claim $^{68}$ or broad claim of a general principle or application. The proposition in Fuel Oils/EXXON ${ }^{69}$ that is the genesis of the approach to insufficiency in Biogen is this: 'that the extent of the monopoly as defined by the claims should correspond to the "technical contribution" to the art in order for it to be supported or justified.' In evaluating its application in Biogen Lord Hoffmann uses 'inventive

\footnotetext{
${ }_{63}$ Mullard Radio Valve Co Ltd v Pbilco Radio and Television Corporation of Great Britain (1936) 53 RPC 323, 347.

${ }^{64}$ Lockwood v Doric (n 54) [63]-[67]

${ }^{65}$ Per Bannon in Kimberly-Clark, Australia Pty Ltd v Arico Trading International Pty Ltd (2001) 207 CLR 1.

${ }^{66}$ Lockwood v Doric (n 54) [67].

67 'A general description of what the invention is said to consist of normally followed by parts of the specification that describe features that 'generally' or 'preferably' exist, and illustrative, rather than exhaustive of how the invention might be put into effect. This kind of clause is identified by the courts as originate from a time before the 1883 Patents, Trademarks and Designs Act which made it compulsory for the first time to list the claims separately: Lockwood v Doric (n 54) [10], [91]-92].

${ }^{68}$ A 'central claim that travels beyond the matter disclosed in the specification': ibid [58] citing Mullard v Philco (n 63) 21.

${ }^{69}$ Fuel Oils/EXXON [1994] OJEPO 653.
} 
concept' interchangeably with 'technical contribution to the art. ${ }^{70}$

In contrast, the House of Lords in Generics is at pains to distinguish between the two concepts - a difficult task in abstraction. Thus:

inventive concept is concerned with the identification of the core of the invention - the idea or principle, of more or less general application which entitles the inventor's achievement to be called inventive. The invention's technical contribution to the art is concerned with the evaluation of its inventive concept - how far forward has it carried the state of the art?

It is crucial to note that the distance and difference between the two concepts is not firmly established as the decision tries to define the extra-statutory 'technical contribution to the art' regularly adopted by the TBA of the EPO. In fact Lord Neuberger notes that the insufficiency reasoning apart from the Biogen reasoning given by Kitchin $\mathrm{J}$ in the lower court was similar to arguments considered on obviousness by the Board in a number of cases. ${ }^{71}$ Further it is the focus on inventive step for product claims that can lead to error; where the claim is for a process or includes a process, the issue of how the alleged invention was achieved, in other words, the inventive step, may be more to the point..$^{72}$ Generics clearly limits the applicability of the Biogen insufficiency principle to rare cases where the claim is to a product identified in part by how it was made and in part by what it did.

Thus although Generics has reconsidered Biogen insufficiency, it also highlights the difficulty in keeping 'inventive step' separate from 'technical contribution to the art' in the context of insufficiency. This problem is unlikely to go away for at least two reasons. First the fair basis objection that endures and can be traced to Fuel Oils/EXXON historically overlaps in the common law with other grounds of invalidity including obviousness. ${ }^{73}$ The second reason is the willingness of the TBA of the EPO to conflate inventive step and inadequacy of disclosure in a line of authority where claims to broad classes of chemical compounds alleged to have some common technical effect have been rejected for obviousness when there is nothing to show that they would all have that technical effect. ${ }^{74}$

Lockwood's rejection of Biogen is suffused with the need to avoid a similar conflation between issues of obviousness and fair basing, which perhaps provides a kinder justification of the divergence than Lord Mance's amusement in Generics

\footnotetext{
${ }^{70}$ Generics v Lundbeck (n 58) [45].

${ }^{71}$ Ibid [89] referring to reasons given by Kitchin J in [2007] RPC 32 [264]-[265].

${ }^{72}$ Ibid [101].

73 TA Blanco White, Patents for Inventions and the Protection of Industrial Designs, $5^{\text {th }}$ edn (London, Stevens and Sons, 1983) [4-801]. However, White did not cite any authorities to support this view, only illustrations based on 'overlapping' provisions. Also see Lockwood Security Products Pty Ltd (n 54) [47].

74 AGREVO/Triazoles T 0939/92 [1996] OJEPO 309. See for example the obviousness analysis in evaluating insufficiency in Scinopharm Taiwan Ltd v Eli Lily and Company [2009] EWHC 631 (Pat) [140][142].
} 
would seem to indicate. ${ }^{75}$ More to the point, the kind of fair basing apparently achieved in Biogen and which persists in EPO jurisprudence is not the same as the words 'fairly based' in section 40(3), where they refer to a relationship between what is claimed and what is described in the body of the specification. They do not refer to 'abstract fairness'.

\section{SPECULATIVE INVENTIONS AND SUFFICIENCY}

The idea of the patent bargain seems almost lyrical and the divergence in interpretations shows the limited value it has as a unifying analytical concept. An emerging theme apparent from the discussion of sufficiency and fair basing, is the manner in which disclosure requirements may overlap with other validity criteria. Such overlap is directly related to the assessment and disclosure of the consideration given in exchange for a patent. This potential source of confusion and error may be further explored in the context of specifications that contain no more than speculative information about the usefulness or industrial application of an invention.

Increasingly, 'utility' under US patent law is being adopted as the terminology of choice to describe the 'usefulness' of an invention over and above 'industrial application', despite several reasons why this conflation may be substantively inaccurate. ${ }^{76}$ Nonetheless, utility elaborated as 'specific, substantial and credible' has been used by the EPO, UKIPO, the UK High Court, ${ }^{77}$ is a part of the new Patents Bill in NZ,78 is included in the Australia-United States Free Trade Agreement, ${ }^{79}$ and figures prominently in international negotiations. ${ }^{80}$

That the correspondence between 'utility' as it is applied in US law and 'industrial application' in the UK is superficial can be gathered from the differences in the relationship between each of these criteria (as conventionally understood) to disclosure and enablement requirements. In US law subsequent to Brenner $v$ Manson ${ }^{81}$ it was established that the enablement requirement, or the chow

\footnotetext{
${ }^{75}$ Generics v Lundbeck (n 58) [56].

76 Some of these include the association of 'industrial' with 'technical', ('utility' does not suffer a similar link), and the public policy concerns associated with 'industrial' that is not matched under 'utility'. For a detailed analysis of these and other differences, see S Thambisetty, 'Legal Transplants in Patent Law: Why "Utility" is the new "Industrial Applicability" (2009) 49 Jurimetrics 155-201.

${ }^{77}$ Eli Lilly and Company v Human Genome Sciences Inc, [2008] EWHC 1903 (Pat) [187] applied by Laboratorios Almirall S A v Boebringer Ingelheim International GmbH [2009] EWHC 102 (Pat).

${ }^{78}$ See $\mathrm{n} 24$. The explanatory notes say that for an invention to be useful, the Bill requires that inventions demonstrate specific, substantial and credible utility.

79 Arts 17.1 and 17.9. Currently in Australian law usefulness is only a ground for opposition and revocation through courts, and is not assessed during examination. Several bodies, including the Australian Law Review Commission and IPAustralia recommend the inclusion of usefulness during examination which would only be satisfied if the specification discloses a specific, substantial and credible use for the invention. 'Getting the Balance Right' (n 32) [5.1].

${ }^{80}$ For example, see WIPO Standing Committee on The Law of Patents, SCP 7/8 (2002) [167], [171].

81 Brenner v Manson 383 US 519 (1966).
} 
to use' prong of $\int 112$ incorporates the requirement of 35 USC $\int 101$ that the specification disclose as a matter of fact a practical utility for the invention. If the application fails as a matter of fact to satisfy $\$ 101$ then the application also fails as a matter of law to enable one of ordinary skill in the art to use the invention. ${ }^{82}$ From here utility in US law has developed as the bridge between speculation and specificity based on actual experimental evidence disclosed or 'well-established' conventions in a technological field. It is this context that brings a threat of confusion between the functional roles of utility and the written description and enablement requirements - a matter of concern for those jurisdictions that have adopted the 'specific, substantial and credible' standard of utility.

In the context of 'speculative inventions', a line of cases has developed in the US where the examiners require further substantiating evidence of utility, unless one with ordinary skill in the art would accept the allegation as obviously correct. Amgen Inc v Chugai Pharmaceutical Co ${ }^{83}$ illustrates this approach. The CAFC invalidated Amgen's broad claims supported by an insufficient number of examples of use. Due to the lack of predictability in the art of isolating and using purified DNA sequences encoding for human erythropoietin the court held that 'for DNA sequences, [an applicant must disclose] how to make and use enough sequences to justify the grant of the claims sought'. ${ }^{84}$ This suggests that if the applicant is able to fully enable his invention the court may have been less stringent in applying utility as a ground for invalidity; correspondingly if the enablement is weak, the court may well demand a complete and specific indication of utility.

The conflation between utility and enablement in US law is often accompanied by sector-specific rules of disclosure that do not apply to other areas - such as in the case of gene sequences ${ }^{85}$ and human gene therapy where the USPTO appears to have set up a presumption that the field itself is unpredictable. ${ }^{86}$ The USPTO Utility Guidelines suggest that the methods to treat unspecified diseases do not meet the substantial utility prong of the specific, substantial and credible test of utility. ${ }^{87}$ Hence claims specifying a pharmaceutical composition without a disease target (a likely scenario, given the state of the art in gene therapy) or specifying a method for introducing genes without a gene therapy

82 Re Zeigler 26 USPQ 1600, 992 F 2d 1197 (Fed Cir 1993) 1200-201.

83 Amgen Inc v Chugai Pharmaceutical Co 927 F 2d 1200, (Fed Cir 1991) 1212-14.

${ }^{84}$ Ibid 1215

${ }^{85}$ For a general discussion of industry specific practice related to written description see DL Burk and M Lemley, 'Policy Levers in Patent Law' (2003) 89 Virginia Law Review 1575.

86 USPTO, 'Training Materials for Examining Patent Applications With Respect to 35 USC $\$ 112$, First Paragraph - Enablement Chemical/Biotechnological Applications (1996), Example G. This is guided in part by an NIH report cited specifically by the USPTO as evidence of the state of the art. SH Orkin and AG Motulsky, 'Report and Recommendation of the Panel to assess the NIH Investment in Research on Gene Therapy', NIH (1995), available at www.nih.gov.news/panelrep.html.

${ }^{87}$ USPTO, Revised Interim Utility Guidelines Training Materials (1999). 
target may fail the substantial utility test, as a result of which an enablement rejection follows. 88

In contrast to the above, industrial application has historically passed through a period of doctrinal confusion between sufficiency and utility and emerged in its present modern form where it is associated with insufficiency of disclosure only in rare cases of extraordinary inventions such as perpetual motion machines. ${ }^{89}$ (While such machines do not have industrial application, an alternate objection may be that the specification is not complete enough to allow the invention to be performed.)

The conceptual link between industrial application and insufficiency in the UK in the period between 1932 and 1977 throws some light on present developments in US law. The overlap and relationship is explained in Valensi v British Radio Corporation Ltd:

The objections of inutility and insufficiency overlap. To prove inutility it is, in our view, necessary to show that the invention so far as claimed, will not work as described or with any modification which the addressee can properly be expected to make. If any proposed modification is one which he cannot be expected to make then the specification is insufficient. ${ }^{\prime} 90$

In Blanco White's words, insufficiency is when you cannot make the thing, inutility is when you can but it doesn't work when you have'. ${ }^{91}$

In order to remove the considerable uncertainty that existed previously in the common law, the UK Patents Act 1932 introduced for the first time, the requirement of 'utility' as a separate ground on which a patent could be revoked in addition to the requirement that the complete specification should sufficiently and fairly describe the nature of the invention and manner in which the invention is to be performed. ${ }^{22}$ From 1932 to 1977 the link between 'utility' and sufficiency was interpreted to mean that every claim in the invention must be useful, ${ }^{93}$ and if a claim covered a mechanism or a process that did not produce the result, or one of the results claimed expressly or impliedly in the specification, the entire patent was deemed invalid. ${ }^{94}$

This was regarded as a harsh position by the Banks Committee which recommended in 1970 that the lack of utility should be a ground for revocation

88 See E Pascal, 'The Heightened Enablement Requirement for Gene Therapy Patents: Is Undue Experimentation the Undoing of Gene Therapy?' (2005) 24 Biotechnology Law Reports 257.

89 See Eastman Kodak Cov American Photo Booths Inc BL/O/457/02 and Manual of UK Patent Practice [4.05].

90 Valensi v British Radio Corporation Ltd [1972] FSR (CA (Civ Div)) 273, 312.

91 Blanco White (n 73) [4-404].

92 s $25(2)(\mathrm{e})$ and s 25(2)(f).

${ }^{3} \mathrm{Ng}$-Loy Wee Loon, 'Patenting of Genes - A Closer Look at the Concepts of Utility and Industrial Applicability' (2002) 33 International Review of Industrial Property and Copyright Law 393, 403.

94 See Norton and Gregory Ltd v Jacobs (1937) 54 RPC 271. This position, according to Ng-Loy Wee Loon, mirrors the literal construction of claims - an approach that was subsequently softened by the 'purposive' approach to claim construction. Loon, 'Patenting of Genes' (n 93) 403-404. 
only if the 'invention claimed covers no useful embodiments'; 95 if part of the subject matter of the application was useful the patent should be granted. Crucially, in order to address the danger of wide and speculative claims being filed the Committee identified the different functional possibilities of sufficiency of disclosure and inutility; it recommended that only the former be used to tackle broad claims. A statutory requirement was therefore proposed to deal with claims that were unduly wide, having regard to the disclosure in the complete specification. ${ }^{96}$ 'Utility' as 'workability' was therefore deemed redundant under the 1977 Act. ${ }^{97}$ Thus:

It is important to remember that the old law which provided for revocation if the claims were not fairly based on the description or lacked utility was swept away by the 1977 Act. The law is now that set out in the 1977 Act. Section 4(1) states that inventions shall be taken to be capable of industrial application 'if it can be made [...] in any kind of industry'. ${ }^{98}$

This observation formalises the different functional roles played by industrial application' and 'sufficiency of disclosure' in modern UK law in contrast to the confusion between utility and disclosure and enablement in US law. While it could be argued that given the common legal history convergence in meaning between 'utility' and 'industrial application' is to be expected, reading the former as fulfilling the latter, at the very least, opens up the possibility of an unwelcome throwback to the confusion that existed between 1932 and 1977 in the common law. Additionally 'utility' as it is championed by the US (via bilateral trade agreements and in WIPO negotiations) does not carry the same weight as usefulness applied under the rubric of 'industrial'. ${ }^{9}$ Convergence in substantive meaning between utility and industrial application in common law jurisdictions calls for thorough judicial scrutiny. So far acceptance of the 'specific, substantial and credible' language in the UK has been piloted not so much by higher courts but by patent office practice - first by the EPO and then the UKIPO. 100

Further, the specific, substantial and credible standard of utility, as it is developing in the US, appears explicitly linked to the state of the art evaluations, in order to ascertain what the patentee has disclosed in relation to what already exists in the field - an enquiry that is better made under the obviousness criterion. In $\mathrm{Re}$

95 Committee on the Patent System and Patent Law, British Patent System: Report of the Committee to Examine the Patent System and Patent Law (1970-71), chaired by Maurice Banks, Cmnd 4407 [376].

96 Ibid [533]. This view coincided with a more 'modern' and favourable view of patents'. UK Patents Act 1977 s 14(3).

97 See Ford J's observations on why 'utility' was dropped in favour of the requirement of sufficiency in Roussel Uclaf v Imperial Chemical Industries plc (No 3) [1991] RPC 51, 67.

98 Chiron Corporation v Murex Diagnostics Ltd [1996] FSR 153, 177 (Morritt LJ).

99 Thambisetty (n 76) 160-170.

100 ICOS Corp/Novel V 28 seven transmembrane receptor 6 OJEPO 293 (2002), Aeomica Inc BL O/286/05. 
Fisher 101 judge Rader notes the conceptual closeness between specific, substantial and credible and the 'inventive step' standard to conclude that policy concerns with inventions such as ESTs are better addressed through non-obviousness - a doctrine considerably hamstrung in US law by the In re Deue ${ }^{102}$ decision.

It is fruitful here to consider the law in Canada that also uses the 'new and useful' terminology. 103 The doctrine of 'sound prediction' reaffirmed by the Canadian Supreme Court in Apotex v Wellcome Foundation Ltd 104 is based on the public interest in the disclosure of new and useful inventions even before their utility has been verified by tests, while avoiding the cluttering of the public domain with useless patents and monopoly rights in exchange for misinformation. ${ }^{105}$ The Supreme Court noted that the key was to avoid 'speculation'. The utility requirement is met at the priority date only if either it is demonstrated or there is sound prediction based on the information and expertise then available. First, there must be a factual basis for the prediction. Secondly, the inventor must have on the date of the patent application, an articulable and sound line of reasoning from which the desired result can be inferred on the factual basis. Thirdly, there must be adequate disclosure of the logic or reasoning used to achieve the prediction. 106 'Sound prediction' does not mean 'certainty' and is a more nuanced bridge between the requirement of 'utility', the cognitive ability to foresee technological innovations and improvements, and the information function of the patent system that requires in various measures sufficient disclosure, enablement, enabling disclosure, or written description.

\section{CONCLUSION}

A major factor in the evolution of sufficiency of disclosure appears to be the increasing 'Europeanisation' of UK law that has, for example, made pre-1977 UK case law more relevant to Australia than post-1977 law. The UK is working ever closer with the EPO both in terms of procedure ${ }^{107}$ and substantive law, ${ }^{108}$ and this can either exacerbate or mitigate the differences with other common law jurisdictions. It has led for example in the case of fair basing, to divergence with Australian law, and in the case of the utility standard to convergence with many other major jurisdictions.

\footnotetext{
101 Re Fisher 421 F 3d 1367 (Fed Cir 2005), 1381-82.

102 Re Deuel 51 F 3d 1552 (Fed Cir 1995).

103 s 2 defines an invention as 'any new and useful art, process, machine, manufacture or composition of matter, or any new and useful improvement in any process, machine, manufacture or composition of matter'.

104 Apotex v Wellcome Foundation Ltd [2002] SCC 77.

105 Ibid [66].

106 Ibid [70].

107 Ibid [66]

108 Ibid [66].
} 
Sufficiency of disclosure is often referred to as an 'internal' requirement of patentability in an attempt to signify that sufficiency is normally assessed after the other substantive criteria have been evaluated, or that it is not quite on par with other grounds of invalidity. However the picture emerging from the above discussion is one of a complex criterion, laced with the 'rhetorical flourish' of the patent bargain, and that in most common law jurisdictions appears to borrow elements from other substantive patentability requirements. Thus in the UK sufficiency has developed a 'fair basing' requirement that assesses 'technological contribution to the art' and in particular contexts, 'non-obviousness'; in the US 'usefulness' and 'enablement' are conflated.

The content of sufficiency thus appears to draw on the approach to other grounds of invalidity determined by how strictly separate they can be or are kept during patentability evaluations that include consideration of more than one ground. Australia appears to have allowed pragmatism to trump complicated explorations of policy and purpose behind sufficiency provisions, and keeping grounds of invalidity separate appears to be a major preoccupation. Other jurisdictions do not seem to be as careful with the juxtaposition of the utility standard and sufficiency. Although the legal history of insufficiency shows overlaps between other grounds of invalidity, the quid pro quo in Liardet refers to the disclosure of the invention, not disclosure of the other substantive requirements such as inventive step or utility of the invention. It is only the common history that ensures in the face of significant diversity in patent disclosure requirements, and potential for confusion and error, that the quid pro quo of the patent bargain endures in spirit in the common law but it is an eviscerated spirit best put to rest. 